HPQ [8].

Có sự khác biệt về điểm CLCS giữa những bênh nhân thuộc các mức kiểm soát hen khác nhau với $p<0,05$, thể hiện rõ nhất ở lĩnh vực triệu chứng và chức năng tình cảm. Mối tương quan giữa điểm $A C T$ và các lĩnh vực của AQLQ12+ từ trung bình đến cao. Trong đó, sự tương quan giữa $A C T$ và các lĩnh vực triệu chứng, tình cảm và tổng thể lần lượt là 0,733 ; 0,623 và $0,686(p=0,00)$, thể hiện mức độ tương quan đồng biến cao. Phân tích của Kosse cho thấy mối tương quan chặt chẽ giữa kiểm soát hen và $\operatorname{CLCS}(r=0,74 ; p<0,001)$ [9]. Như vậy, việc nâng mức kiểm soát sẽ giúp làm tăng CLCSsức khỏe cho bệnh nhân hen, và có thể xem mức kiểm soát hen là môt yếu tố dư báo cho CLCS-sức khỏe ở bệnh nhân HPQ. Tương quan giữa \%FEV1 và điểm AQLQ12+ là tương quan đồng biến ở mức thấp $(r=0,334 ; p=0,02)$.

\section{KẾT LUÂ̂N}

HPQ ảnh hưởng đến CLCS của TTN ở mức độ trung bình. Miền cảm xúc và giới hạn hoạt động có ảnh hưởng lớn nhất đến CLCS. Các yếu tố như giới, mức độ nặng, tuân thủ điều trị và kiểm soát hen ảnh hưởng đến CLCS. Trong đó kiểm soát hen là yếu tố có ảnh hưởng cao nhất.

\section{TÀI LIÊU THAM KHẢO}

1. Kaplan A, Price D. Treatment Adherence in Adolescents with Asthma. J Asthma Allergy 2020; 13:39-49.

2. Miadich SA, Everhart RS, Borschuk AP et al. Quality of Life in Children With Asthma: A Developmental Perspective. J Pediatr Psychol 2015; 40(7):672-679.

3. Alvim CG, Ricas J, Camargos PAM et al. Prevalência de transtornos emocionais e comportamentais em adolescentes com asma. J Bras Pneumol 2008; 34(4):196-204.

4. Schatz M, Christine AS, PharmD et al. Asthma Control Test: Reliability, validity, and responsiveness in patients not previously followed by asthma specialists. The journal of allergy and clinical immunology 2006; 117(3):549-556.

5. Chen D. Assessing the medication adherence report scale as a tool in pediatric asthma. Thesis (M.A.)-Boston University 2012

6. Juniper EF, Svensson $K$, Mörk AC et al. Modification of the asthma quality of life questionnaire (standardised) for patients 12 years and older. Health Qual Life Outcomes 2005; 3(1):58.

7. Burkhart PV, Svavarsdottir EK, Rayens MK et al. Adolescents with asthma: predictors of quality of life. J Adv Nurs 2009; 65(4):860-866.

8. Kosse RC, Koster ES, Kaptein AA et al. Asthma control and quality of life in adolescents: The role of illness perceptions, medication beliefs, and adherence. J Asthma 2020,57(10):1145-1154.

\title{
KỸ THUÂT TAO HÌNH ĐƯờNG TIÊU HÓA TRÊN CHO BÊNH NHÂN PHẢI CẮT BỎ TOÀN Bộ THỰC QUẢN VÀ DẠ DẦY PHÂN TÍCH TỔNG HợP 3 TRƯờnG HợP
}

\section{TÓM TẮT}

Mục tiêu: Đánh giá kỹ thuật tạo hình đường tiêu hóa trên bằng hồi - đai tràng phải cho bênh nhân cắt bỏ toàn bộ thực quản và dạ dày. Đối tượng và phương pháp nghiên cứu: Mô tả hồi cứu 1 bênh nhân nam 61 tuổi chẩn đoán ung thư biểu mô tế bào vảy $1 / 3$ giữa thực quản và ung thư biểu mô tế bào tuyến kém biệt hóa ở $1 / 3$ giữa da dày và 2 bệnh nhân nữ 43 tuổi và 37 tuổi được chẩn đoán bỏng đường tiêu hóa trên gây co rút chít hẹp, thắt chặt thực quản và da dày do hóa chất ăn mòn đã được phẫu thuât cắt bỏ toàn bộ thực quản và dạ dày, tạo hình đường tiêu hóa trên tại Khoa Ngoại tổng hợp Bệnh viện Bach Mai

*Bệnh viện Bạch Mai

Chịu trách nhiệm chính: Trần Manh Hùng

Email: tranmanhhungngoaibm@gmail.com

Ngày nhận bài: 3.6.2021

Ngày phản biên khoa học: 27.7.2021

Ngày duyệt bài: 5.8 .2021

\section{Trần Mạnh Hùng* và CS}

từ 5/ 2020 đến 5/2021. Kết quả nghiên cứu: Thời gian mổ là 5 giờ; không có tai biến phẫu thuật; không phải truyền máu trong và sau mổ; một trường hợp viêm phổi sau mố; thời gian nằm viện sau mổ là 12 ngày, 9 ngày và 18 ngày; Kiểm tra, theo dõi sau mổ bệnh nhân khỏe mạnh, ăn uốn tốt, không bị trào ngược và đã tăng cân. Kết luận: Tạo hình đường tiêu hóa trên bằng hồi đại tràng phải cho những bệnh nhân phải cắt bỏ toàn bộ dạ dày và thực quản an toàn và hiệu quả.

Ti̛ khóa: cắt thực quản, cắt da dày, cắt toàn bô thực quản và da dày, tạo hình đường tiêu hóa trên bằng hồi - đại tràng phải.

\section{SUMMARY}

TECHNEQUE IN FORMATION OF THE UPPER DIGESTIVE TRACT FOR PATIENTS WHO UNDERWENT TOTAL ESOPHAGOGASTRECTOMY APOOLED NALYSIS OF 3 PATIENTS

Objective: Techneque in formation of the upper 
digestive tract by the ileum - right colon for patient who underwent total esophagogastrectomy. Subjects and research methods : A 61 year old male patient with esophageal squamous epithelium carcinoma and gastric adenocarcinoma, two cases of women (43 and 37 year old) with simultaneous burns of both esophagus and stomach due to caustic chemicals, which subsequently caused retraction, stricture, and tightening of the entire esophagus and stomach, were successfully operated by esophago-gastrectomy and the reconstruction of upper gastrointestinal tract at Bach Mai Hospital. Results: The surgery lasted 5 hours, the patient lost $300-350 \mathrm{ml}$ of blood without blood transfusion during and after surgery. The operation went well without any complications. The patient were discharged from hospital at 12th day, 18th day, 9th day post-surgery. All 3 cases were scheduled for follow-up examination, patients were able to eat and drink without any signs of reflux, having gained 2 to $3 \mathrm{~kg}$. Conclusion: Formation of the upper digestive tract by the ileum - right colon for patient who underwent total esophagogastrectomy safely and effectively.

Keywords: esophagus cut, stomach cut, total esophagogastectomy, formation the upper digestive tract by ileum - right colon.

\section{I. ĐĂT VẤN ĐỀ}

Việc thiết lập lại đường tiêu hóa trên là hết sức quan trọng cho những bệnh nhân phải cắt bỏ đồng thời cả thực quản và dạ dày, là yếu tố quyết định chất lượng cuộc sống sau phẫu thật. Một câu hỏi được đặt ra là đoạn ống tiêu hóa nào được sử dụng để thay thế sau khi cắt bỏ đồng thời thực quản và dạ dày để đảm bảo đủ dài, có mạch máu nuôi dưỡng tốt và hạn chế trào ngược? Dạ dày là giải pháp tiềm năng, chiếm ưu thế cho những bệnh nhân phải cắt bỏ thực quản vì da dày có chiều dài tốt, nguồn cung cấp mạch máu tốt và chỉ cần một đường nối duy nhất. Tuy nhiên, khi mà da dày không có (do không còn hay phải cắt bỏ cùng thực quản), phẫu thuật viên phải lựa chọn đoạn ống tiêu hóa nào để thay thế cho cả da dày và thực quản đã bi cắt bỏ. Các lựa chọn hiện tại để thay thế là đại tràng, hỗng tràng. Chúng tôi báo cáo một phân tích tổng hợp kỹ thuật tạo hình đường tiêu hóa trên bằng hồi - đại tràng phải sau khi cắt bỏ toàn bộ dạ dày và thực quản cho 3 trường hợp bênh nhân.

\section{II. ĐỐI TƯỢNG VÀ PHƯƠNG PHÁP NGHIÊN CỨU}

2.1 Đối tượng nghiên cứu: $B a$ ca lâm sàng trong báo cáo phân tích tổng hợp của chúng tôi bao gồm: 1 trường hợp ung thư đồng thời cả thực quản và dạ dày, hai trường hợp bỏng đường tiêu hóa trên do hóa chất ăn mòn gây co rút, chít hẹp thắt chặt toàn bộ thực quản và dạ dày.

2.2 Phương pháp nghiên cứu: Mô tả hồi cứu 3 trường hợp bệnh nhân đã được phẫu thuật cắt bỏ toàn bộ thực quản và dạ dày, tạo hình đường tiêu hóa trên bằng hồi - đại tràng phải tại Khoa Ngoại tổng hợp Bệnh viện Bạch Mai từ 5/ 2020 đến 5/2021

2.3 Kỹ thuật phẫu thuật: Một quy trình phẫu thuật tổng quát cho cả 3 trường hợp được tóm tắt như sau: 1. Mổ mở hoặc mổ nội soi, cắt bỏ thực quản ngực, 2. Mở bụng đường trắng giữa trên dưới rốn, cắt bỏ toàn bộ dạ dày, 3 . Mở đường chữ J ở cổ bên trái, cắt ngang qua thực quản cổ trên vị trí tổn thương, 4. Giải phóng hồi - đại tràng phải, giữ lại động mach đại tràng phải trên, đại tràng phải giữa, các cung viền của hồi manh đại tràng, thắt gốc động mạch hồi manh đại trùng tràng, cắt bỏ ruột thừa, cắt ngang qua hồi tràng cách van Bauhin $8 \mathrm{~cm}$, cắt ngang qua đại tràng ngang ở vị trí cung Riolan, 5. Đưa hồi đại tràng phải qua trung thất sau lên cổ trái, nối thực quản cổ với hồi tràng tận - tận, tận - bên hay bên - bên, nối đại tràng ngang phải với quai hỗng tràng đầu tiên tận - bên, nối hồi - đại tràng ngang phía bên trái. Kỹ thuật tạo hình đường tiêu hóa trên bằng hồi - đại tràng phải được mô tả bởi hình vẽ sau:
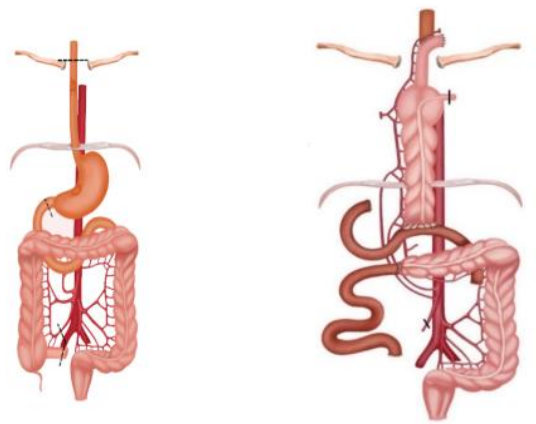

Hinh 1: Mô tả kỹ thuật tạo hinh đường tiêu hóa trên bằng hồi - đại tràng phải cho bệnh nhân phải cắt bỏ đồng thời cả thực quản và dạ dày [1]

\section{KẾT QUẢ NGHIÊN CứU}

3.1 Trường hợp thứ nhất: Bệnh nhân nam 61 tuổi, nông dân, có biểu hiện đau bụng vùng thượng vị và nuốt nghẹn một tháng trước đó, đi khám được chỉ định soi dạ dày. Kết quả soi cho thấy có tổn thương ở thực quản cách cung răng trên $25 \mathrm{~cm}$ được sinh thiết; soi xuống dạ dày phát hiện tổn thương ở góc bờ cong nhỏ $1 \mathrm{~m}$, bờ ghồ cao, sinh thiết. Kết quả sinh thiết ung thư biểu mô tế bào vảy ở thực quản và ung thư biểu mô tuyến kém biệt hóa ở da dày. Các xét nghiệm về huyết học, sinh hóa, chức năng hô hấp bình thường. Siêu âm nội soi tổn thương T1 ở thực quản, T2 ở dạ dày. Chụp CT SCANER ngực và 
bụng có chất cản quang không thấy tổn thương bất thường ở trung thất và ổ bụng, soi đại tràng kiểm tra cho kết quả bình thường. Chẩn đoán ung thư biểu mô vảy thực quản T1NoMo, ung thư biểu mô tuyến kém biệt hóa của dạ dày T2NoMo. Phẫu thuật cắt toàn bộ dạ dày, thực quản ngực, tạo hình đương tiêu hóa trên bằng hồi đại tràng ở cổ trái được phẫu thuật ngày 28 tháng 5 năm 2020. Kỹ thuật: Mở bụng đường trắng giữa trên rốn, kiểm tra các tạng không có bất thường, cắt bỏ toàn bộ mạc nối lớn, nhỏ, thắt các mạch máu dạ dày, nạo vét hạch $\mathrm{DI}$ và DII, cắt thực quản theo phương pháp Oringer. Mở vùng cổ, bộc lộ thực quản, cắt ngang qua thực quản cổ cách khớp ức đòn $3 \mathrm{~cm}$, lấy hạch cố, lấy bỏ toàn bộ dạ dày và thực quản cả khối. Giải phóng hồi đại tràng phải, cắt ngang qua hồi tràng cách góc hồi manh tràng $8 \mathrm{~cm}$, cắt bỏ ruột thừa. Đưa hồi đại tràng phải qua trung thất sau lên cổ. Nối thực quản cổ với hôi tràng bằng máy nối tròn $25 \mathrm{~mm}$ tận bên, nối đầu dưới đại tràng phải với quai hỗng tràng đầu tiên tận - bên, nối hồi tràng đại tràng ngang bằng stapler thẳng $75 \mathrm{~mm}$. Ca mổ kéo dài 5 giờ, mất $300 \mathrm{ml}$ máu, không phải truyền máu sau mổ. giải phẫu bệnh sau mổ T1bNoMo với ung thư thực quản, T2aNoMo với ng thư dạ dày, 19 hạch viêm mãn tính, sau phẫu thuật bệnh nhân khổng điều trị bổ trợ gì. Kiểm tra 9 tháng sau mổ bệnh nhân khỏe mạnh, ăn uống tốt, không có trào ngược, tăng được $3 \mathrm{~kg}$. Kiểm tra lại sau mổ 15 tháng bệnh nhân khỏe mạnh, tăng $5 \mathrm{~kg}$.

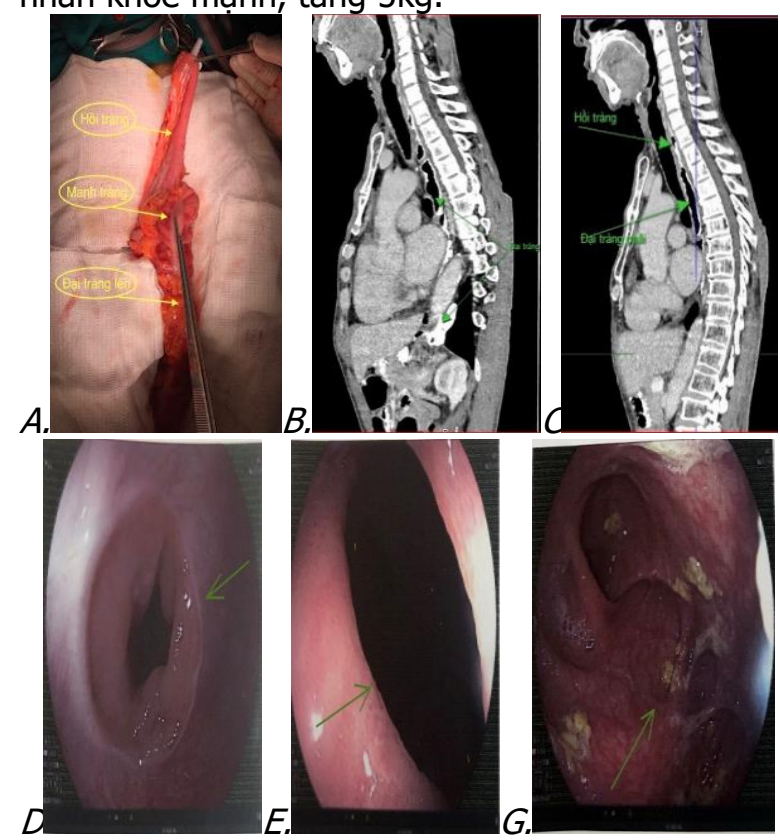

Hinh 2: A. Hối đại tràng phải đưa lên để tạo hình,
B,C. Chụp CT kiểm tra Iưu thông thực quản - hồi tràng - đại tràng - hỗng tràng sau phẩu thuật 9 tháng, D miệng nối thực quản - hồi tràng, E. Van

Bauhin, G. Đại tràng phải sau mô 9 tháng

3.2 Trường hợp thứ 2. Nữ bệnh nhân 43 tuổi, kinh doanh, cao 1m60, nặng $73 \mathrm{~kg}$ (BMI $28,5)$, uống một loại thuốc giảm cân có tên là HERBAL 450 mg với liều 2 viên / ngày, ngoài ra bênh nhân không dùng thêm bất kỳ một loại thuốc nào khác. Sau 1 tháng uống thuốc, bệnh nhân xuất hiện nôn mửa, nuốt nghẹn tăng dần, chỉ uống được nước cháo, sữa và không thể ăn được chất đắc, đã đến khám và điều trị tại Bênh viện Bạch Mai. Kết quả nội soi phát hiện nhiều sẹo gây hẹp thực quản, bắt đầu từ $1 / 3$ trên thực quản, cách cung răng $25 \mathrm{~cm}$, Chụp cắt lớp ngực bunng thấy thực quản và dạ dày có tổn thương dày thành, có các khí giữa các lớp, thể tích dạ dày nhỏ. Bệnh nhân được nội soi và nong thực quản nhưng không có kết quả và được chuyển đến Khoa Ngoai tổng hợp, sau uống thuốc giảm cân 2 tháng, sút $26 \mathrm{~kg}$ (BMI 18,3). Chúng tôi bồi phụ nước điện giải, nuôi dưỡng hoàn toàn bằng đường tĩnh mạch $2.500 \mathrm{kcal} / 24$ giờ. Sau hai tuần người bệnh tắng $4 \mathrm{~kg}$. Kiểm tra các xét nghiện sinh hóa, huyết học trong giới hạn bình thường. Nội soi kiểm tra lại thấy thực quản hẹp khít, cách cung răng $25 \mathrm{~cm}$. Chụp Xquang thây thực quản và dạ dày hẹp hoàn toàn, dạ dày teo nhó, có rất ít thuốc xuổng được dạ dày. Bệnh nhân được chẩn đoán trước mổ là sẹo bỏng gây chít hẹp toàn bộ thực quản và da dày do hóa chất ăn mòn và được chỉ định phấu thuật để cắt bỏ toàn bộ dạ dày và thực quản, tạo hình đường tiêu hóa trên bằng hồi đại tràng phải ngày $6 / 4 / 2021$. Thì ngực ở tư thế nghiêng trái, sấp 45 độ, phẫu thuật nội soi ngực bên phải với 4 trocar, giải phóng toàn bộ thực quản ngực, đặt dẫn lưu lồng ngực bên phải và đóng các lố trocar. Sau đó bệnh nhân được chuyển tư thế nằm ngửa để mở bụng ở đường trắng giữa trên và dưới rốn. Kiểm tra thấy dạ dày co rút lại còn rất nhỏ $(10 \times 5$ $\mathrm{cm})$, thành dạ dày viêm dính, dày lên. Mở dạ dày kiểm tra thây niêm mạc dạ dày có nhiều sẹo loét co rúm lại không còn chỉ định bảo tồn, vì vậy đã cắt bỏ toàn bộ dạ dày. Mở đường cổ bên trái hình chữ J, giải phóng thực quản cổ, cắt ngang qua thực quản cổ trên chỗ hẹp, lấy bỏ toàn bộ thực quản và da dày qua đường bụng. Giải phóng hồi đại tràng phải, đưa hồi đại tràng phải qua trung thất sau lên cổ, nối thực quản cổ với hồi tràng bên- bên bằng stapler $75 \mathrm{~mm}$, nối đâu đại tràng ngang với quai hỗng tràng đầu tiên tận - bên bằng chỉ safil $4 / 0$, nối hỗng - đại tràng 
ngang bên - bên bằng stapler $75 \mathrm{~mm}$. Ca mổ diễn ra trong 5 tiềng, quá trình phẫu thuật diễn ra thuận lợi. Ngày thứ 5 sau mổ, bệnh nhân có triệu chứng viêm phổi, nuôi cây dịch phế quản cho kết quả vi khuẩn P.seudomonas aeruginosa, và được điều trị Meronem 3gram/ 24 giờ kết hợp lý liệu pháp, nuôi dưỡng qua sonde mũi 2.500 kcal/ 24 giờ. Ngày thứ 12 sau mổ, bệnh nhân ổn định, được rút sonde mũi và cho ăn bằng đường miệng tiếp nhận tốt. Bệnh nhân xuất viện ngày
24/4/2021 (sau mổ 18 ngày). Tái khám, nội soi kiểm tra sau 2 tuần, 1 tháng, 2 tháng sau khi ra viện. Kết quả nội soi và chụp lưu thông đường tiều hóa trên sau 2 tháng phẫu thuật cho thấy: miêng nối thực quản - hồi tràng lưu thông tốt, miệng nối đại tràng ngang hổng tràng bình thường, thuốc lưu thông tốt từ thực quản xuống hồi tràng - đại tràng - hỗng tràng, bệnh nhân ăn uống được, không có dấu hiệu trào ngược và đã tăng 2 kg.

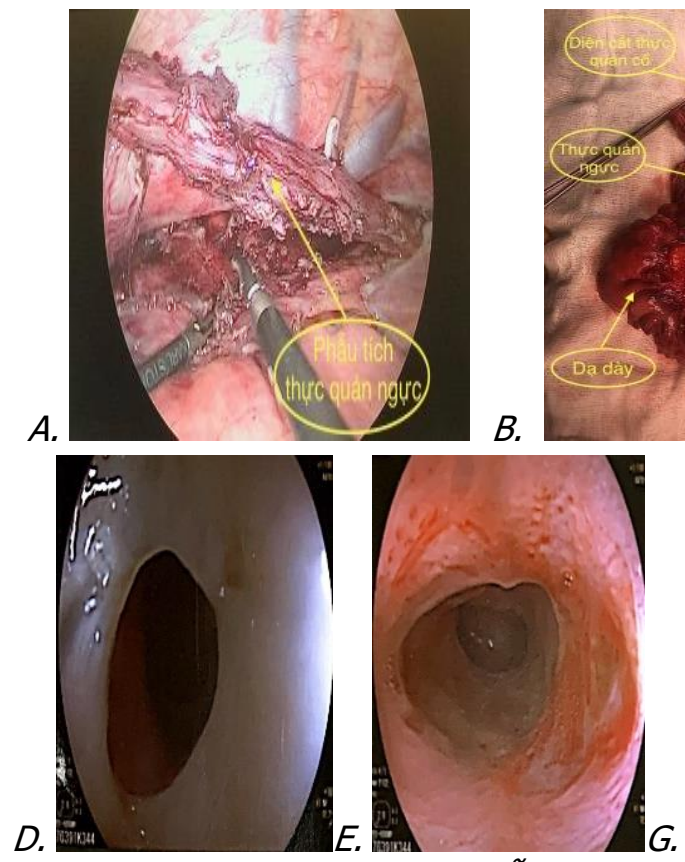

Hinh 3, trường hợp thứ hai: Phẫu thuật că

A. phẫu thuâat nội soi ngực cắt thực quản ngực; $B$. Da dày và thực quản bị cắt bỏ (Trái), hồi đại tràng phải được đưa lên để tạo hình (phải); $\mathrm{C}$. Tổn thương thực quản và da dày teo nhỏ, chít hẹp do thuốc giảm cân; D. Miệng nối thực quản hồi tràng, $\mathrm{E}$. miệng nối đại tràng hỗng tràng, $\mathrm{G}$, $\mathrm{H}$. Chụp lưu thông thực quản - hồi - đại tràng hỗng tràng thẳng và nghiêng 2 tháng sau mổ.

3.3 Trường hợp thứ ba: Nữ bệnh nhân 37 tuổi, làm ruộng, cao $1 \mathrm{~m} \mathrm{54}$, nặng $63 \mathrm{~kg}$ (BMI 26,5), mâu thuấn với chồng, uống khoảng $50 \mathrm{ml}$ nước tẩy rửa bồn cầu tự tử, sau khi uống nước rửa bồn cầu 8 tiếng được chuyển đến cấp cứu tại trung tâm chống độc Bệnh viện Bạch Mai. Sau 1 tháng điều trị tại đầy, bệnh nhân xuất hiện nuốt nghen, không ắn uống được. Nội soi thực quản thấy hẹp ở $1 / 3$ trên, cách cung răng $20 \mathrm{~cm}$, dây soi thường không qua được, soi bằng dây soi mũi. Kết quả cho thấy thực quản nhiều sẹo loét, co rúm, tâm vị hẹp, da dày nhiêu seo, thể tích bé, môn vị hẹp khít. Chụp CT scanner ổ bụng cho thấy da dày có tổn thương dày thành, có các khí giữa các lớp, thể tích dạ dày nhỏ. Bệnh nhân được chúng tôi phẫu thuật nội soi nối vị tràng và mở thông da dày để nuôi dưỡng. Sau 1 tháng nuôi dưỡng qua mở thông dạ dày, tăng được 4 kg. Phẫu thuật ngày $4 / 5 / 2021$, các bước của ca mổ được thực hiện như trường hợp thứ hai. Điểm khác với 2 ca đầu là nối thực quản cổ với hồi tràng tận - tận bằng chỉ safil 4/0. Ca mổ kéo dài 5 giờ, không gặp khó khăn gì trong quá trình phẫu thuật, hậu phẫu thuận lợi, bệnh nhân xuất viện ngày 13/5/2021 (sau mổ 9 ngày). Tái khám, nội soi kiểm tra sau 2 tuần, 1 tháng, 2 tháng sau khi ra viện. Kết quả nội soi và chụp lưu thông đường tiểu hóa trên sau 2 tháng phẩu thuật cho thây: miêng nối thực quản - hồi tràng lưu thông tốt, miệng nối đại tràng ngang hống tràng bình thường, thuốc lưu thông tốt từ thực quản xuống hồi tràng - đại tràng - hỗng tràng, bệnh nhân ăn uống được, không có dấu hiệu trào ngược và đã tăng 3 kg. 
A.

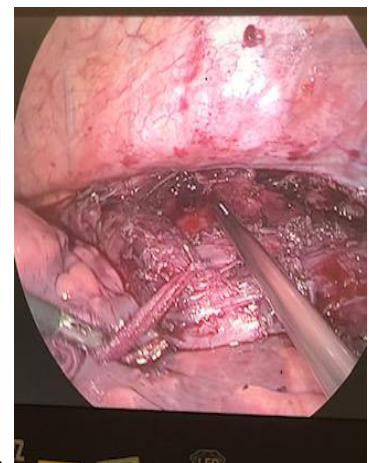

B.

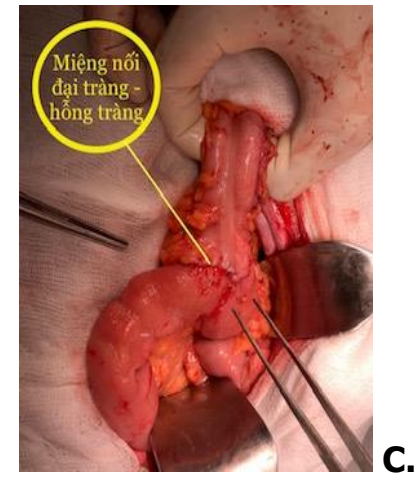

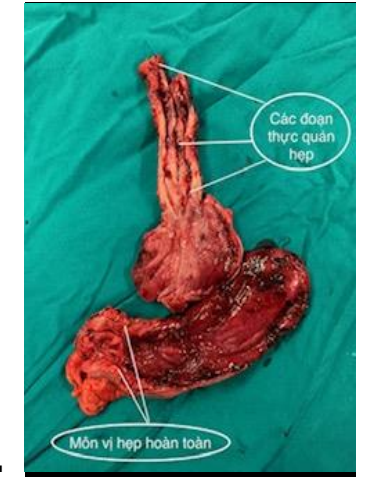

\section{D.}
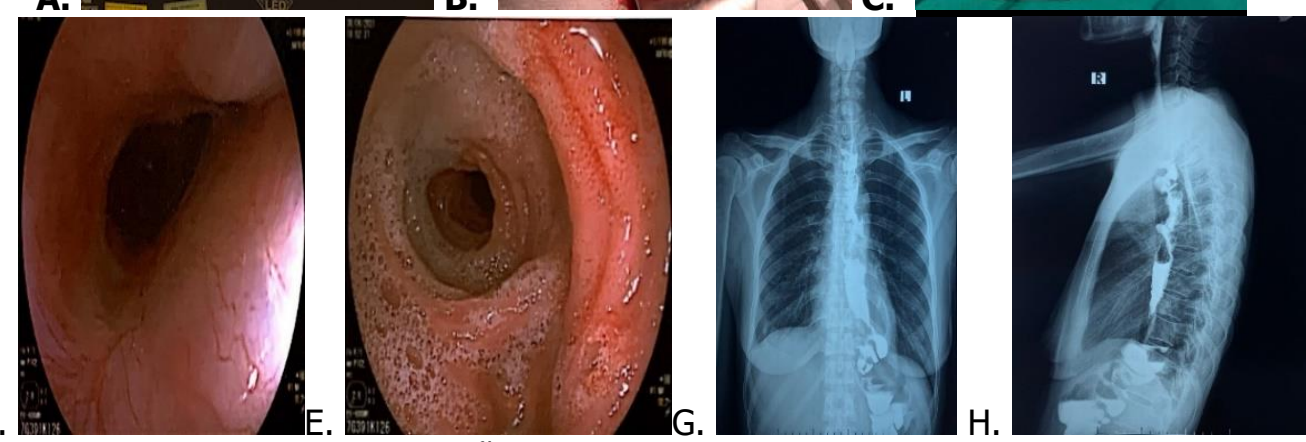

Hình 4, trường hợp thứ 3: Phẫu thuật cắt bỏ, tạo hinh và kiểm tra lại sau 2 tháng

A. Phẫu thuật nội soi cắt thực quản ngực; B: Miệng nối đại tràng ngang - hống tràng; $C$. Da dày và thực quản teo nhỏ, chít hẹp do nước tẩy rửa bồn cầu được cắt bỏ, D. Miệng nối thực quản hồi tràng, $\mathrm{E}$. Van Bauhin, G, H. Chụp lưu thông thực quản - hồi - đại tràng - hổng tràng thẳng và nghiêng 2 tháng sau mồ.

\section{BÀN LUÂ̂N}

Theo hiểu biết của chúng tôi, cho đến nay có rất ít các báo cáo về tạo hình đường tiêu hóa trên cho những bệnh nhẩn tổn thương đồng thời cả thực quản và da dày, các báo cáo chủ yếu là các ca lâm sàng và đoạn ống tiêu hóa được sử dụng để thay thể cho thực quản và dạ dày thương là đại tràng, hỗng tràng có cuống hay một phần dạ dày còn lại sau khi đã cắt bỏ tổn thương. Chúng tôi cho rằng, việc lựa chọn đoạn ống tiêu hóa nào để thay thế tùy thuộc vào 3 yếu tố: Một là vị trí, kích thước, giai đoạn của tổn thương; Hai là giải phâ̂u và chức năng sinh lý bình thường của đoạn ống tiêu hóa định sử dụng để thay thế và ba là kinh nghiệm của phấu thuật viên.

Năm 1992 Bassiouny IE và cộng sự thông báo sử dụng đại tràng để tạo hình đường tiêu hóa trên [2], Maier $A$ và cộng sự (2002) báo cáo sử dụng hổng tràng có cuống để thay thế sau cắt bó toàn bộ thực quản và dạ dày [3]. Motoyama và cộng sự [4] năm 2015 mô tả phương pháp cắt dạ dày đoạn dưới, bảo tồn phần trên của dạ dày và các mạch máu bên phải, tạo ống dạ dày, cắt thực quản, nối ống da dày thực quản trong ngực, dạ dày hống tràng Roux - en -Y để điều trị cho trường hợp ung thư kép ở1/3 dưới thực quản và phần thấp da dày. Kỹ thuật này đã được Yunpeng Zhao, MD tiếp cận và thực hiện thành công cho 3 trường hợp đồng thời cùng bị ung thư biểu mô vảy của thực quản và ung thư biểu mô tuyến của dạ dày. Trên cơ sở đó tác giả đề nghị cắt da dày đoạn xa, bảo tồn các mạch máu bên phải da dày, kết hợp với cắt thực quản Ivor Lewis qua nội soi lồng ngực để điêu trị cho những bệnh nhân vừa ung thư thực quản vừa ung thư biểu mô tuyến của da dày khi khối u thực quản cách cung răng trên ít nhất $27 \mathrm{~cm}$ giai đoạn II $a$, khối $u$ da dày nằm ở đoạn xa được đánh giá giai đoạn iâm sàng $\mathrm{I} a$ [5]. Ninh $\mathrm{T}$ và cộng sự 2007 [6 ] báo cáo trường hợp cắt thực quản xâm lấn tối thiểu Ivor Lewis, có sử dụng đại tràng phải để điều trị ung thư tâm vị dạ dày lan đến thân vị dạ dày và $1 / 3$ dưới thực quản. Honda $M$ và cộng sự [7] báo cáo trường hợp phẫu thuật nội soi cắt thực quản ngực, cắt toàn bộ dạ dày và sử dụng đại tràng phải tái tạo đường tiêu hóa trên bằng miệng nối thực quản đại tràng ở ngực để điều trị cho trường hợp ung thư thực quản $1 / 3$ dưới và ung thư $1 / 3$ giữa của da dày. Bita Shahbazzadegan báo cáo hai trường hợp bỏng thực quản và dạ dày do hóa chất ăn 
mòn đã được phẫu thuật thay thế thực quản bằng đại tràng trái và đại tràng ngang. Tuy nhiên, cả hai trường hợp này dạ dày vẫn được bảo tồn [8].

Ba bệnh nhân của chúng tôi trong đó bệnh nhân số 1 là ung thư biểu mô vảy thực quản giai đoạn I b, cách cung răng trên $25 \mathrm{~cm}$, ung thư biếu mô tuyến da dày giai đoạn IIa kém biệt hóa ở góc bờ cong nhỏ vì vậy chúng tôi lựa chọn chỉ định phẫu thuật mở bụng, cắt toàn bộ dạ dày nạo vét hạch, cắt thực quản ngực theo phương pháp Oringer, giải phóng hồi đại tràng, tạo hình đường tiêu hóa trên bằng hồi - đai tràng phải bằng miệng nối thực quản - hồi tràng ở cổ bên trái (Hình 2 : A, B, C). Hai trường hợp thứ hai và thứ ba trong báo cáo của chúng tôi đều bị bỏng do hóa chất ăn mòn để lại biến chứng nghiêm trọng là sẹo hẹp gây co rút, thắt chặt toàn bộ thực quản và dạ dày không thể bảo tồn. Vì vậy chúng tôi đã lựa chọn phẫu thuật nội soi ngực để cắt thực quản ngực, mở bụng để cắt bỏ dạ dày và giải phóng hồi đại tràng và sử dụng hổi đại tràng phải để tạo hình lại đường tiêu hóa trên cũng bằng miệng nối thực quản - hồi tràng ở cổ trái (Hình 3,4: A, B, C). Đây là sự lựa chọn hợp lý, an toàn và hiệu quả cho cả 3 trường hợp. Chúng tôi cho rằng để có được kết quả phẩu thuật tốt cho những trường hợp đặc biệt này cần phải đảm bảo các yêu cầu sau: 1) Phải chuẩn bị bệnh nhân tốt, đánh giá cẩn thận, chính xác các tổn thương. 2) Phải kiểm tra, đánh giá đoạn ống tiêu hóa dư kiến thay thế. 3) Phải được thực hiện bới các phẫu thuật viên có kinh nghiệm[9], [10].

Các bệnh nhần của chúng tôi đều được theo dõi, hẹn tái khám định kỳ sau mổ đều ăn uống tốt, không có dấu hiệu trào ngược và đều tăng cân. Điều này còn được minh chứng bằng kết quả nội soi và chụp lưu thồng đường tiêu hóa của cả 3 bệnh nhân đều rất tốt (Hình 2,3,4: $D, E, G, H$ )

Theo hiểu biết của chúng tôi thì đây là những trường hợp đầu tiên sử dụng hồi đại tràng phải để tạo hình đường tiêu hóa trên cho những bệnh nhân phải cắt bỏ đồng thời cả thực quản và dạ dày được thông báo trong y văn. Qua kết quả của các trường hợp này chúng tôi thấy rằng sử dụng hồi đại tràng phải để thay thế đường tiêu hóa trên an toàn và hiệu quả, là sự lựa chọn tốt để tạo hình đường tiêu hóa trên cho những bệnh nhân phải cắt bỏ đồng thời cả thực quản và dạ dày vì các lý do sau:

1. Hồi đại tràng phải là đoạn ống tiêu hóa đủ dài để nối giữa thực quản ở cổ hay thậm chí từ ngã ba hầu họng với ổ bụng.
2. Hồi đại tràng phải có nguồn cung cấp mạch máu tốt, đảm bảo dinh dưỡng miệng nối và chức năng vận chuyển thức ăn.

3. Van Bauhin được bảo tồn rất có ý nghĩa trong việc ngăn chặn hiện tượng trào ngược về sau.

\section{KẾT LUẬN}

Hồi đại tràng phải là đoạn ống tiêu hóa được sử dụng tốt để tạo hình đường tiêu hóa trên an toàn và hiệu quả cho những bệnh nhân phải cắt bỏ toàn bộ dạ dày và thực quản.

\section{TÀI LIỆU THAM KHẢO}

1. Tran MH, Tran TPT, Nguyen TK, Hoang VM. Formation of the upper Digestive tract by the ileum - right colon for patient with concurrent cancers of the esophagus and the stomach: A case report. International Journal of Surgery Case Reports 2021,85: 106232.

2. Bassiouny IE, Bahnassy AF. Transhiatal esophagectomy and colonic interposition for caustic esophageal stricture. J Pediatr Surg. 1992;27(8):1091 - 5. [PubMed] [Google Scholar].

3. Maier A, Pinter $H$, Tomaselli F, Sankin O, Gabor S, Ratzenhofer-Komenda B, et al. Retrosternal pedicled jejunum interposition: an alternative for reconstruction after total esophagogastrectomy. EurJCardiothoracSurg. 2002;22(5):66 1-5. [PubMed] [Google Scholar].

4. Motoyama S, Saito $R$, Okuyama $M$, et al. Treating gastric tube cancer with distal gastrectomy preserving the gastroepiploic artery. Ann Thorac Surg 2006;81:751-3. [PubMed] [Google Scholar]

5. Yunpeng Zhao, MD and Bo Cong, MD*.A new surgical procedure for synchronous esophageal squamous cell carcinoma and gastric adenocarcinoma. Case report: three cases reports.

6. Ninh T, Nguyen MD, Hinojosa $M$, et al. Thoracoscopic Ivor Lewis esophagectomy with colonic interposition. Ann Thorac Surg 2007;84:2120-4. [PubMed] [Google Scholar]

7. Honda M, Daiko H, Kinoshita T, et al. Minimally invasive resection of synchronous thoracic esophageal and gastric carcinomas followed by reconstruction: a case report. Surg Case Rep 2015;1:12. [PMC

article] [PubMed] [Google Scholar]

8. Bita Shahbazzadegan, free Samadzadeh, Iraj Feizi, and Yousef Shafaiee. Management of Esophageal Burns Caused by Caustic Ingestion: A Case Report Iran Red Crescent Med J. 2016 Nov; 18(11): e12805. $\begin{array}{llll}\text { Published online } & 2016 & \text { Mar }\end{array}$ doi: $10.5812 /$ ircmj. 12805.

9. Siew Min Keh, Nzewi Onyekwelu, Kieran McManus, Jim McGuigan. Corrosive injury to upper gastrointestinal tract: Still a major surgical dilemma: Acase Report. World J Gastroenterol. 2006 Aug 28;12(32):5223-8. doi: 10.3748/wjg.v12.i32.5223. PMID: 16937538. PMCID: PMC4088025. 